\title{
BLEEDING AND STARVING: fasting and delayed refeeding after upper gastrointestinal bleeding
}

\author{
Jorge FONSECA ${ }^{1,2}$, Tânia MEIRA ${ }^{1}$, Ana NUNES ${ }^{1}$ and Carla Adriana SANTOS ${ }^{1}$
}

\begin{abstract}
Context - Early refeeding after nonvariceal upper gastrointestinal bleeding is safe and reduces hospital stay/costs. Objective The aim of this study was obtaining objective data on refeeding after nonvariceal upper gastrointestinal bleeding. Methods - From 1 year span records of nonvariceal upper gastrointestinal bleeding patients that underwent urgent endoscopy: clinical features; rockall score; endoscopic data, including severity of lesions and therapy; feeding related records of seven days: liquid diet prescription, first liquid intake, soft/solid diet prescription, first soft/solid intake. Results - From 133 patients (84 men) Rockall classification was possible in 126: 76 score $\geq 5,50$ score $<5$. One persistent bleeding, eight rebled, two underwent surgery, 13 died. Ulcer was the major bleeding cause, 63 patients underwent endoscopic therapy. There was $142 / 532$ possible refeeding records, no record $37 \%$ patients. Only $16 \%$ were fed during the first day and half were only fed on third day or later. Rockall $<5$ patients started oral diet sooner than Rockall $\geq 5$. Patients that underwent endoscopic therapy were refed earlier than those without endotherapy. Conclusions - Most feeding records are missing. Data reveals delayed refeeding, especially in patients with low-risk lesions who should have been fed immediately. Nonvariceal upper gastrointestinal bleeding patients must be refed earlier, according to guidelines.
\end{abstract}

HEADINGS - Gastrointestinal hemorrhage. Nutrition. Ulcer. Endoscopy gastrointestinal.

\section{INTRODUCTION}

The Nonvariceal Upper Gastrointestinal Bleeding (NVUGIB) is a frequent cause for hospitalization $^{(4,6,8,11,14,17,20)}$. Recent clinical studies demonstrate that the outcome of these patients can be improved when clinical resources are improved, decreasing the recurrence of bleeding ${ }^{(2,13,15,19)}$, the need for transfu$\operatorname{sion}^{(13,19)}$ and surgery ${ }^{(13)}$ and reducing the length of stay and hospital costs ${ }^{(13,19)}$.

A simple measure to enhance the outcome of NVUGIB patients could be the improvement of the timing when resuming a regular diet. There was a traditional idea that fasting could reduce gastric secretion, and thus could be useful as an adjuvant measure to heal ulcers and other bleeding lesions. This, however, has never been proved. On the contrary, a 2003 study addressed the question of the potential secretory stimulus of oral feeding in NVUGIB patients and found that gastric secretion of patients under antisecretory drugs was scarcely affected by feeding ${ }^{(16)}$. Although there are only a few published studies on the subject of resuming oral feeding of NVUGIB patients, not a single advises fasting. More than 20 years ago, a prospective randomized study compared two groups, one receiving a regular diet immediately after bleeding, and other group receiving no oral nutrition for 36 hours, followed by clear liquids for 12 hours, and a regular diet thereafter. In this study refeeding protocol did not influenced the patient's hospital course ${ }^{(10)}$. Two more recent randomized studies proved that early feeding did not worsen outcome and furthermore enables early discharge and reduces the costs of treatment ${ }^{(5,9)}$. Disregarding the available evidence, scientific societies of gastroenterologists and other professionals dealing with NVUGIB rarely address the question of restarting feeding of NVUGIB patients. Nevertheless, some guidelines recommend an early refeeding. The 2003 consensus, promoted by the Canadian Association of Gastroenterology, suggests immediate oral feeding in patients with low risk ulcers and Mallory-Weiss tears ${ }^{(1)}$. Also, the guidelines from the British Society of Gastroenterology Endoscopy Committee suggest the introduction of liquid diet 4 to 6 hours after endoscopy with or without a therapeutic procedure $^{(3)}$. Generally, it is consensual that patients with low risk lesions should resume oral intake immediately, and those with high risk lesions should probably be refed a short period after endoscopy.

To the best of our knowledge, there are few systematic studies on refeeding after a NVUGIB episode. There is a subjective awareness that nutrition of

Declared conflict of interest of all authors: none

${ }^{1}$ Hospital Garcia de Orta Serviço de Gastrenterologia, Grupo de Estudo de Nutrição Entérica - GENE, Pragal, Almada, Portugal: ${ }^{2}$ Instituto Superior de Ciências da Saúde Egas Moniz. Quinta da Granja, Monte da Caparica, Almada, Portugal.

Correspondence: Jorge Fonseca. Hospital Garcia de Orta, Serviço de Gastrenterologia, Grupo de Estudo de Nutrição Entérica - GENE. Av. Prof. Torrado da Silva, 2800 Pragal, Almada, Portugal. E-mail: jorgedafonseca@gmail.com 
NVUGIB patients is largely overlooked in many hospitals. The major aim of this retrospective study was obtaining objective data on refeeding patients after a NVUGIB episode, in the real live context of a Portuguese large hospital. The specific aims were:

1. After a NVUGIB episode, evaluate the time span until resuming oral intake.

2. Evaluate the differences of feeding management between patients and bleeding lesions with high and low rebleeding risk.

3. Evaluate the quality of clinical records on refeeding after NVUGIB episode.

\section{METHODS}

From the records of upper gastrointestinal (GI) endoscopy, we selected all the patients that underwent urgent endoscopy for NVUGIB since January, 1st to December, 31 st of 2008. Once the patients were identified through the index endoscopy, the clinical files of the episode were evaluated. This particular year was chosen because it was the last year in which most hospital data was recorded in paper files.

As a rule, every upper GI bleeding patient is submitted to urgent endoscopy in the admission day. For the purpose of the present study the day of the index endoscopy was day one. From the clinical files, we collected:

1. Clinical features of the patients and the NVUGIB episodes.

2. Severity of the NVUGIB episodes, using the Rockall score $^{(18)}$

3. Endoscopic data including:

a. Endoscopic diagnosis.

b. Severity of the lesions according with Forrest classification ${ }^{(7)}$ Lesions classified as Forrest Ia, Ib and IIa were labeled as high risk lesions.

c. Use of endoscopic therapy.

4. Feeding related records of the first seven days in the hospital, including:

a. Record of prescription of liquid diet.

b. Record of first liquid intake.

c. Record of prescription of soft/solid diet.

d. Record of first soft/solid intake.

Patients previously hospitalized (in-hospital upper GI bleeding) and patients with hospital stay shorter than 24 hours were excluded.

Results are presented as descriptive statistics using the Excel software. The statistical analysis was performed with the Statistical Package for Social Sciences (SPSS, version 20.0). All statistical tests were performed at the $5 \%$ level of significance. Independent Sample t-test was used to assess the differences of refeeding days between groups with or without endoscopic therapy and between groups with low or high Rockall score. For equality of variances, the Levene's test was used.

\section{RESULTS}

From the urgent upper GI endoscopy files we selected 175 patients with a NVUGIB episode. Forty-two were excluded because hospital stay was shorter than 24 hours. We identified files from 133 patients with a NVUGIB episode longer than 24 hours, with a mean age of 71 years, $84(63 \%)$ men and 49 women. Records from 126 patients allowed classification according Rockall score, $76(60 \%)$ having a clinically severe (score $\geq 5$ ) bleeding episode and $50(40 \%)$ having a mild episode. One case presented a persistent bleeding after the index endoscopy, and underwent surgery. Only eight cases suffered a rebleeding episode (two presenting Rockall $<5$ and six with Rockall $\geq 5$ ) and one of these severe cases needed surgery to control the rebleeding episode. Thirteen patients died within thirty days following the NVUGIB episode, all of them after the 7th day of hospitalization. These included the two cases that underwent surgery for the initial NVUGIB and for a rebleeding episode. The remaining 11 deceased patients died from causes not directly related with the hemorrhage: cardiovascular (4), renal (2), hepatic (2) or respiratory (1) failure, or sepsis ( 2 patients).

All patients were subject to urgent endoscopy. Identifying the bleeding lesions was possible in most of them. Only 11 cases had no lesion found, although 7 out of these 11 presented blood in the stomach and were considered to be inconclusive (Table 1). Ulcer, gastric or duodenal, was the most frequent cause of bleeding, accounting for $62 \%$ of the cases. Almost half, 37 patients, presented ulcers with high risk stigmata, Forrest Ia, Ib and IIa lesions. Endoscopic therapy was performed in $63(47 \%)$ patients, including all patients presenting high risk ulcers and other high risk lesions.

TABLE 1. Endoscopic diagnosis

\begin{tabular}{lcc}
\hline Diagnosis & $\mathbf{n}$ & $\%$ \\
\hline Duodenal ulcer & 42 & 31.6 \\
Gastric ulcer & 40 & 30 \\
Erosive gastritis/duodenitis & 9 & 6.8 \\
Neoplasia & 5 & 3.8 \\
Oesophagitis & 6 & 4.5 \\
Angiodysplasia & 8 & 6 \\
Dieulafoy ulcer & 5 & 3.8 \\
Mallory-Weiss & 3 & 2.3 \\
Barrett's oesophagus & 2 & 1.5 \\
Polyps & 1 & 0.8 \\
Hiatal hernia ulcer & 1 & 0.8 \\
Blood in the stomach & 7 & 5.3 \\
No blood or lesion & 4 & 3 \\
\hline
\end{tabular}


Searching for the refeeding records, there were 142 out of the 532 possible and appropriate:

- 53 prescriptions of liquid diet,

- 51 records of first liquid intake,

- 18 prescription of soft/solid diet, and

- 20 records of soft/solid diet intake.

Only 84 patient files out of $133(63 \%)$ had some type of refeeding record and only three files presented all four records (Table 2).

TABLE 2. Number of refeeding records of each patient

\begin{tabular}{ccc}
\hline Number of refeeding records & Number of patients & $\%$ \\
\hline 1 & 49 & 37 \\
2 & 41 & 31 \\
3 & 31 & 23 \\
4 & 3 & 7 \\
\hline
\end{tabular}

Using the first record, prescription or oral intake, as the first oral feeding day, we estimated that oral refeeding started at the first day in only $14 \%$ of patients, at the second day in $36 \%$, at the third day in $30 \%$, at the fourth day $8 \%$ and $12 \%$ of patients at the fifth day or later.

From these 84 patients, it was possible to achieve a Rockall classification in 81. By splitting them according to the Rockall score, we found 30 patients with mild bleeding episodes (score $<5$ ) and a median refeeding on day 2 , and 51 with severe bleeding episodes (score $\geq 5$ ) and a median refeeding on day 3 . This difference is not statistically significant $(P=0.297)$ (Figure 1$)$.

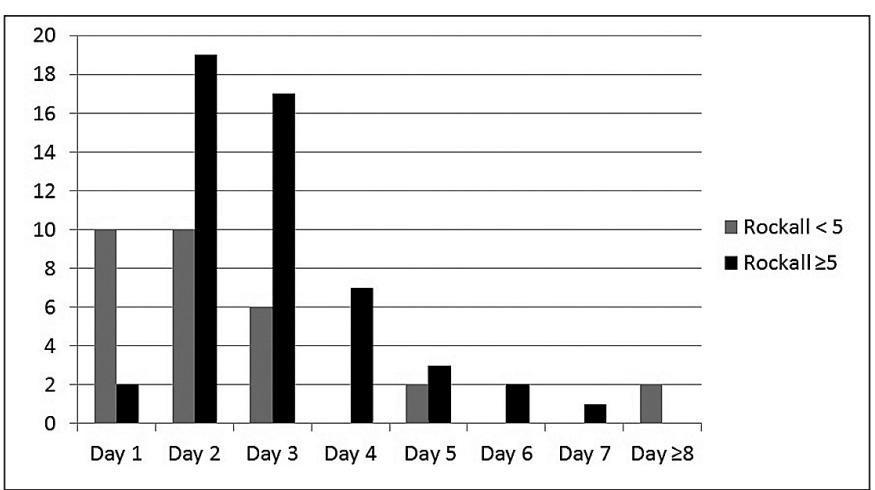

FIGURE 1. Refeeding day according with Rockall severity score

We additionally split these 84 patients according to presence or absence of endoscopic therapy, a surrogate marker for the severity of lesions found at the index endoscopy. The 34 patients that underwent endoscopic therapy displayed a median refeeding on day 2 , and 50 without therapy displayed a median refeeding on day 3 . This difference is not statistically significant $(P=0.430)$ (Figure 2$)$.

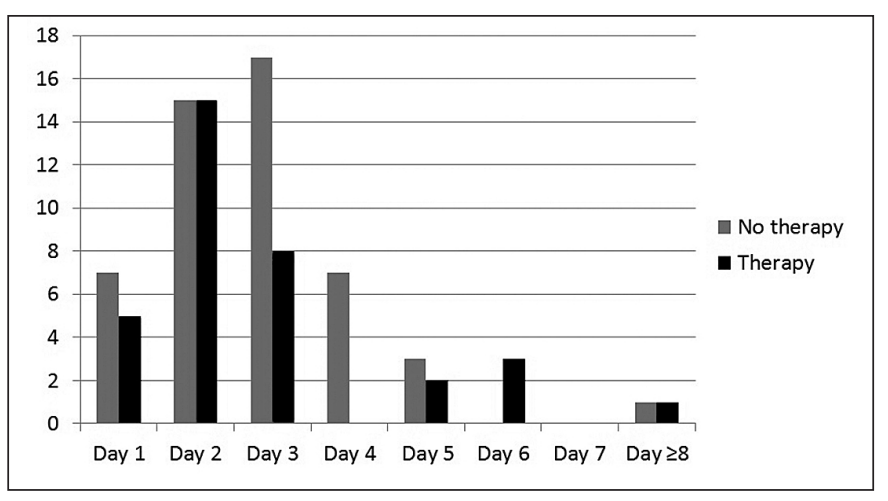

FIGURE 2. Refeeding day according with endoscopic therapy

Reviewing the clinical files of the patients that underwent a rebleeding episode, we verified that all of them, including the one that needed surgery, resumed oral intake before the rebleeding episode, and thus this adverse outcome did not interfere with the nutritional decisions. In addition, the patient that underwent surgery for the initial NVUGIB was tube fed before dying from a surgery complication. All the other 11 deceased patients that passed away from non-bleeding conditions were orally or tube fed during the hospitalization. Refeeding records from all these patients with adverse outcomes (persistent bleeding, rebleeding, surgery or death) were collected and evaluated with the same methodology as data from patients with better outcome.

\section{DISCUSSION}

In the recent years, NVUGIB outcomes have been improved as result of the introduction and spreading of new therapeutic approaches, both pharmacological and endoscopic. Nevertheless, there is still some significant mortality associated with NVUGIB episodes ${ }^{(13,19)}$. A recent international, multicentric, pan-European study revealed that, despite some variations, clinical management of NVUGIB is similar throughout 123 Hospitals across all Europe ${ }^{(12)}$. Management of NVUGIB was also similar at the 12 Portuguese centers enrolled in this European study ${ }^{(6)}$. Having achieved an high standard on pharmacological and endoscopic approaches, teams taking care of NVUGIB patients must improve other aspects of management, namely organizational issues ${ }^{(6)}$. Nutritional approach is surely one of those issues. It has been evidenced that early refeeding is safe ${ }^{(10,16)}$ and may reduce hospital stay and treatment costs ${ }^{(5,9)}$. It is recommended by the guidelines ${ }^{(1,3)}$. Nevertheless, nutrition of NVUGIB patients seems to be undervalued in every-day clinical practice.

The aim of the present study was to obtain objective data on refeeding patients after a NVUGIB episode in a real live practice, but it has some limitations. One of them was the 
focus on the year 2008 instead of a later year, but we believe that there is no major change in the clinical practice. Moreover, in later years, nutritional records could be even lower or scattered between paper and several computer clinical data bases. Some patients that had mild NVUGIB with a hospital stay shorter than 24 hours were excluded. Conversely, as the bleeding episodes were looked after through an index emergence endoscopy, patients with very severe NVUGIB might have been submitted to emergence surgery without previous endoscopy, failing inclusion. This is an unlikely case but not an impossible one. Hence some patients with very mild or very severe NVUGIB may have been excluded from the study. Finally, the evaluation is based on the recorded data, which proved to be very poor, but these are the limitations of a retrospective, "real life" study, and the lack of records is also important information.

One of the aims of the present study was the evaluation of the quality of clinical records on refeeding after NVUGIB episode. We found 142 out of $532(27 \%)$ of the intended refeeding records of 133 patients. Moreover, $37 \%$ did not have any record, but we believe that $1 / 3$ of our patients had not been fasting during one week, some of which until the discharge. There is poor recording of feeding data and, as far as we can see, this reflects insufficient attention paid to nutritional issues.

Another aim of this study was evaluating the time span until oral intake was resumed, following a NVUGIB episode. Our available data points towards only $16 \%$ of patients being fed at first day. Half of the patients resumed oral intake at the third day or later. More than a half of the patients (53\%) presented low risk lesions and was not submitted to any kind of endoscopic treatment. These patients should have started oral feeding in Day 1.

Focusing on the 84 patients with feeding records, it was possible to achieve a Rockall classification in 81 of them. The 30 patients with Rockall score $<5$ (mild) display a median refeeding on day 2 , sooner than the 51 with Rockall score $\geq 5$ (severe), which presented a median refeeding on day 3 . As expected, those who were clinically more unstable restart oral nutrition after a larger interval.

Splitting these 84 patients according to the index endoscopy, the 34 that underwent endoscopic therapy presented a median refeeding on day 2 , which seems satisfactory.
Resuming oral intake on Day 2 indicates that the first meal is provided around 24 hours after endoscopic intervention. Resuming oral diet could have probably been sooner in some patients, but a 24-hour delay is acceptable for endoscopically treated patients with high risk lesions. Conversely, the other 50 patients without endoscopic therapy displayed a median refeeding on day 3 , which is clearly inadequate. Patients with low risk lesions that did not undergo endoscopic treatment should start oral nutrition immediately after recovering from the urgent endoscopy. The finding of a later refeeding in non-treated patients, when compared to the endoscopically treated ones, is a paradox and challenging to explain. This cannot be a matter of poor written information of patients with low risk lesions. Looking at all the 133 patients, feeding records were present in 34 of the 63 patients that underwent endoscopic therapy (54\%), and in 50 of the $70(71 \%)$ who did not underwent such therapy. Patients without high risk lesions do not present feeding records less frequently, which indicated that this may not be a problem of lack of data. A possible explanation may be that patients with milder lesions inspire less concern, get less attention, and are refed later than those with high risk lesions and endoscopic therapy.

Globally, available data points towards a late restart of oral feeding for most of NVUGIB patients. For some patients that presented high risk endoscopic lesions and/or endoscopic therapy, refeeding timing may be accurate or near accurate, but concerning the patients with low risk lesions delayed refeeding was clearly inadequate.

\section{CONCLUSIONS}

The present study confirms that nutritional issues are undervalued in the clinical management of NVUGIB patients. Most desirable feeding records were missing and circa one third of all the patients presented no nutritional data from the first week after the bleeding. The available data reveals that refeeding is clearly delayed. Major delay is evident in patients with low risk endoscopic lesions who should be fed immediately after the urgent endoscopy. Teams taking care of NVUGIB patients must be aware of the advantages of early oral nutrition of these patients, and should follow the available international guidelines and recommendations. 
Fonseca J, Meira T, Nunes A, Santos CA. Hemorragia e jejum: jejum e reintrodução alimentar tardia após episódios de hemorragia digestiva alta. Arq Gastroenterol. 2014,51(2):128-32

RESUMO - Contexto - A reintrodução alimentar precoce após hemorragia digestiva alta de causa não varicosa é segura, reduz internamento/custos hospitalares. Objetivo - O objetivo deste estudo retrospectivo foi avaliar a realimentação após hemorragia digestiva alta de causa não varicosa. Métodos Dos processos dos doentes submetidos a endoscopia urgente por hemorragia digestiva alta de causa não varicosa, durante 1 ano, recolhemos: dados clínicos; classificação de Rockall; dados endoscópicos; registos nutricionais de 7 dias: prescrição de líquidos, primeira ingestão líquida, prescrição de dieta mole/sólida, primeira ingestão de dieta mole/sólida. Resultados - Em 133 doentes (84 homens), a classificação Rockall foi possível em 126: 76 score $\geq 5,50$ score $<5$. Uma hemorragia inicial persistente, 8 recidivas hemorrágicas, dois doentes submetidos a cirurgia, 13 falecidos. A úlcera foi a lesão predominante, 63 doentes submetidos à terapêutica endoscópica. Encontraram-se $142 / 532$ registos nutricionais possíveis, 37\% sem qualquer registo. Só $16 \%$ foram realimentados no $1 .^{\circ}$ dia, metade foram realimentados no $3 .^{\circ}$ dia ou posteriormente. Doentes com Rockall <5 foram realimentados mais cedo que com Rockall $\geq 5$. Doentes com terapêutica endoscópica foram realimentados mais cedo que sem terapêutica. Conclusões - Falta a maioria dos registos. Os dados mostram realimentação tardia, sobretudo nos doentes com lesões de baixo risco que deveriam alimentar-se imediatamente. Doentes com hemorragia digestiva alta de causa não varicosa devem iniciar precocemente a alimentação, de acordo com as recomendações.

DESCRITORES - Hemorragia gastrointestinal. Nutrição. Úlcera. Endoscopia gastrointestinal.

\section{REFERENCES}

1. Barkun A, Bardou M, Marshall JK; Nonvariceal Upper GI Bleeding Consensus Conference Group. Consensus recommendations for managing patients with nonvariceal upper gastrointestinal bleeding. Ann Intern Med. 2003;139:843-57.

2. Barkun A, Sabbah S, Enns R, Armstrong D, Gregor J, Fedorak RN, et al. The Canadian Registry on Nonvariceal Upper Gastrointestinal Bleeding and Endoscopy (RUGBE): endoscopic hemostasis and proton pump inhibition are associated with improved outcomes in a real-life setting. Am J Gastroenterol. 2004;99:1238-46.

3. British Society of Gastroenterology Endoscopy Committee. Non-variceal upper gastrointestinal haemorrhage: guidelines. Gut. 2002;51:iv1-6.

4. Button LA, Roberts SE, Evans PA, Goldacre MJ, Akbari A, Dsilva R, et al. Hospitalized incidence and case fatality for upper gastrointestinal bleeding from 1999 to 2007: a record linkage study. Aliment Pharmacol Ther. 2011;33:64-76.

5. de Lédinghen V, Beau P, Mannant PR, Ripault MP, Borderie C, Silvain C, et al. Quand faut-il reprendre l'alimentation orale après hémorragieulcéreuse gastro-duodénale? Etude contrôlée randomisée [When should patients with bleeding peptic ulcer resume oral intake? A randomized controlled study]. Gastroenterol Clin Biol. 1998;22:282-5.

6. Fonseca J, Alves CC, Neto R, Arroja B, Vidal R, Macedo G, et al. Nonvariceal upper gastrointestinal bleeding in Portugal: a multicentric retrospective study in twelve Portuguese hospitals. Gastroenterol Hepatol. 2012;35:377-85.

7. Forrest JA, Finlayson ND, Shearman DJ. Endoscopy in gastrointestinal bleeding. Lancet. 1974;2: 394-7.

8. Kapsoritakis AN, Ntounas EA, Makrigiannis EA, Ntouna EA, Lotis VD, Psychos AK, et al. Acute upper gastrointestinal bleeding in central Greece: the role of clinical and endoscopic variables in bleeding outcome. Dig Dis Sci. 2009;54:333-41.

9. Khoshbaten M, Ghaffarifar S, Jabbar Imani A, Shahnazi T. Effects of early oral feeding on relapse and symptoms of upper gastrointestinal bleeding in peptic ulcer disease. Dig Endosc. 2013;25:125-9.

10. Laine L, Cohen H, Brodhead J, Cantor D, Garcia F, Mosquera M. Prospective evaluation of immediate versus delayed refeeding and prognostic value of endoscopy in patients with upper gastrointestinal hemorrhage. Gastroenterology. 1992;102:314-6.
11. Lanas A, Aabakken L, Fonseca J, Mungan ZA, Papatheodoridis GV, Piessevaux $\mathrm{H}$, et al. Clinical predictors of poor outcomes among patients with nonvariceal upper gastrointestinal bleeding in Europe. Aliment Pharmacol Ther. 2011;33: 1225-33.

12. Lanas A, Aabakken L, Fonseca J, Mungan Z, Papatheodoridis G, Piessevaux H, et al. Variability in the management of nonvariceal upper gastrointestinal bleeding in Europe: an observational study. Adv Ther. 2012;29:1026-36.

13. Leontiadis GI, Sharma VK, Howden CW. Systematic review and meta-analysis: proton-pump inhibitor treatment for ulcer bleeding reduces transfusion requirements and hospital stay-results from the Cochrane Collaboration. Aliment Pharmacol Ther. 2005;22:169-74.

14. Loperfido S, Baldo V, Piovesana E, Bellina L, Rossi K, Groppo M, et al. Changing trends in acute upper-GI bleeding: a population-based study. Gastrointest Endosc. 2009;70:212-24.

15. Muller T, Barkun AN, Martel M. Non-variceal upper GI bleeding in patients already hospitalized for another condition. Am J Gastroenterol. 2009;104:330-9.

16. Ozawa T, Yoshikawa N, Tomita T, Akita Y, Mitamura K. The influence of feeding on gastric acid suppression in Helicobacter pylori-positive patients treated with a proton pump inhibitor or an $\mathrm{H} 2$-receptor antagonist after bleeding from a gastric ulcer. J Gastroenterol. 2003;38:844-8.

17. Rockall TA, Logan RF, Devlin HB, Northfield TC. Incidence of and mortality from acute upper gastrointestinal haemorrhage in the United Kingdom. Steering Committee and members of the National Audit of Acute Upper Gastrointestinal Haemorrhage. BMJ. 1995;311:222-6.

18. Rockall TA, Logan RF, Devlin HB, Northfield TC. Selection of patients for early discharge or outpatient care after acute upper gastrointestinal haemorrhage. National Audit of Acute Upper Gastrointestinal Haemorrhage. Lancet. 1996;347:1138-40.

19. Sung JJ, Barkun A, Kuipers EJ, Mössner J, Jensen DM, Stuart R, et al. Intravenous esomeprazole for prevention of recurrent peptic ulcer bleeding: a randomized trial. Ann Intern Med. 2009;150:455-64.

20. Targownik LE, Nabalamba A. Trends in management and outcomes of acute nonvariceal upper gastrointestinal bleeding: 1993-2003. Clin Gastroenterol Hepatol. 2006;4:1459-66. 